\title{
Poesía y violencia política en los poetas de los años noventa en el Perú (revisión panorámica y estudio del caso de Ya nadie incendia el mundo, de Victoria Guerrero)
}

\section{Poetry and Political Violence in the Poets of the 90's in Peru (A Panoramic Review and a Study Case: Victoria Guerrero's Ya nadie incendia el mundo)}

\author{
Luis Fernando Chueca \\ Universidad de Lima \\ Pontificia Universidad Católica del Perú
}

\section{RESUIMEN}

Los poetas de llamada "poesía peruana de los 90" evitaron, en general, referirse expresamente al proceso de violencia política de los años ochenta y noventa en el país. Esto ha llamado la atención, porque se trató de un proceso que impactó su biografía en sus años de formación y de participación inicial en el campo literario. Luego del año 2000, sin embargo, varios de estos mismos poetas decidieron enfrentar sus propios silencios y entregaron libros que evidencian no solo voluntad de memoria y mirada crítica y lúcida frente al proceso vivido, sino que ofrecen también una interesante reflexión metapoética en torno a las posibilidades de la escritura que se enfrenta a este tipo de situaciones. Todo ello con madurez expresiva. El propósito de este artículo es presentar el proceso de esta promoción poética frente a la violencia política: por un lado, indagar en los factores literarios, sociales e ideológicos decisivos en la gestación del silencio mencionado y explorar algunas de las formas en que, a pesar de este, procesaron la violencia en sus textos. Por otro, señalar las circunstancias en que recuperan la voz y la memoria poética acerca de estos hechos y mencionar algunas de las principales líneas que siguen estos nuevos trabajos. Sobre esto último se revisa el caso del poemario Ya nadie incendia el mundo (2005) de Victoria Guerrero.

Palabras clave:

Poesía / Violencia política / Memoria / Victoria Guerrero

\section{ABSTRACT}

Poets of the "Peruvian poetry of the 1990s" generally avoided to make express reference to the political violence lived in Peru in the 1980s and 1990s. It is a curious fact since that period impacted their lives, during their education and initial participation in the literary field. After 2000 , however, many of them decided to face their own silences and wrote books showing not only the will of memory and the critical and lucid view of the process, but also an interesting metapoetic reflection on the possibilities of writing in such situation. All this with an expressive maturity. The purpose of this paper is to present the process of this poetic promotion against the political violence: on the one hand, to investigate the decisive literary, social and ideological factors in the gestation of the mentioned silence and to explore some of the ways in which they processed the violence in their texts. On the other, to point out the circumstances in which they recover the voice and poetic memory about these facts and to mention some of the main concepts developed in these new works. This paper reviews the poetry book Ya nadie incendia el mundo (2005) written by Victoria Guerrero.

Keywords:

Poetry / Political Violence / Memory 


\section{Poesía y violencia política en los poetas de los noventa: Ios silencios iniciales}

Una pregunta reiterada en las revisiones y discusiones sobre la "poesía peruana de los noventa", es decir, la que corresponde a los jóvenes que comenzaron a publicar en dicha década, es por qué durante varios años esta promoción casi no abordó, de manera expresa, en sus poemas, la guerra interna de los años ochenta y noventa (1980-1992), ni la dictadura civil-militar de Fujimori (1992-2000), procesos centrales en el contexto de crecimiento y formación de gran parte de sus integrantes, así como (sobre todo la dictadura) de los años iniciales de su acercamiento y participación en el campo literario'. La pregunta encierra dos aspectos que es necesario comentar. El primero, la suposición de la obligación - 0 al menos responsabilidad- de hacerlo, o de que cualquier referencia a la violencia debiera ser explícita. Me interesa dejar claro, al respecto, que no busco adjudicar tareas no asumidas, sino comprender procesos que llaman la atención. Y este silencio sobre la violencia política ha llamado la atención por la magnitud de los acontecimientos, por el contraste con lo ocurrido con la promoción anterior de poetas y porque, en gran medida, esa actitud coincidió con la de una parte de la población que prefirió, en esos mismos años, por desconcierto, miedo, comodidad o aletargamiento, no profundizar, casi, en lo que se estaba viviendo, en sus causas centenarias ni en sus implicancias.
Por otro lado, esta poesía - aunque, salvo excepciones, no abordara explícitamente estos procesos - no pudo sustraerse de su mundaneidad, pues, como señala Said, "todo texto literario se encuentra de algún modo lastrado por la ocasión en que se produjo, por las simples realidades empíricas de las que emergió" (2004, p. 54). Inevitablemente, entonces, los silencios que refiero, pero también la búsqueda formalista de un lenguaje "despolitizado", la apelación a los espacios privados, la desrealización textual, la consagración de un panorama de diversidad de registros sin hegemonía reconocible, así como, más evidentemente, la indagación en las escenografías urbanas de descomposición social -todos estos rasgos centrales de la producción de los jóvenes de los noventa en dicha década ${ }^{2}$ - representaron modos como esta poesía y estos poetas afrontaron las circunstancias que les tocó vivir.

Comentaré algunos de estos rasgos. Pero primero, respecto de la magnitud del silencio (descontando los poemas de Montserrat Álvarez, a quien me referiré después), puede señalarse que, de un corpus de poemas publicados entre el noventa y el año 2000, pertenecientes a más de ochenta poetas de la promoción, no se encuentran más de cinco textos que refieren explícitamente la violencia política ${ }^{3}$. Y no son más de diez los poetas involucrados en estos acercamientos, si se consideran también los textos que, alegórica u oblicuamente, remiten a ella, al menos con cierta posibilidad de que esto sea reconocido. No cabe duda de que un silencio tan generalizado como este no puede dejar de llamar la atención e, inevitablemente, se vuelve síntoma, al cotejarlo con su contexto de producción, de la conflictiva relación de estos poetas con lo que se vivía en esos momentos.

El único caso excepcional es Zona dark de Montserrat Álvarez, aunque en su momento se percibió más bien como un anuncio de que la joven promoción continuaría el interés de la anterior por acercarse a la difícil situación del país. Zona dark, aparecido en 1991, el primer poemario de Álvarez y uno de los libros inaugurales de la promoción, remite a la guerra interna explícita y consistentemente, tanto con menciones directas a acontecimientos de esta, cuanto estableciendo relaciones implícitas entre la guerra y la larga historia peruana de discriminación étnica y social que constituye una de sus causas. Todo ello expresado con un lenguaje directo, sardónico y corrosivo que deja percibir un clima apocalíptico en una escenografía callejera de deterioro. Una muestra del modo de acercamiento de Zona dark a la violencia política es el poema "Los relojes se han roto":

En estos días de paro armado y carestía, días de microbuses atropellados y de comensales / engullidos, cuando hay tanta cerveza por beber en estos días, digo, en estos días, la sangre y la cerveza derramadas se suben a la frente con más sed En estos días en los que la muerte es un adorno más para la vida, las horas del futuro se han venido al presente; los relojes se han roto, o se los han robado. (p. 139)

Como en varios de los poemas de la sección "De nosotros decid", en donde se ubica este texto, las imágenes de desvarío y descomposición, propias de un contexto marcado por el derrumbe del horizonte utópico, el nihilismo y la crisis de las ideologías, también profusa-

1 Lo dicho en esta parte quizá debería enunciarlo en primera persona de plural, pues se trata de la promoción con la que comencé a publicar y tuve, en general, mis primeras lecturas públicas, aunque, de todos modos, parte de mi formación y mi acercamiento al campo literario se haya dado en la década anterior. Mantengo, no obstante, la convención del uso de la tercera persona.

2 He trabajado sobre estas características en la "poesía de los 90", en Chueca 2001 y 2009.

3 El corpus aludido es el que revisé para Chueca 2001. Es claro que no se trata de un registro completo; no obstante, sí corresponde a una muestra bastante representativa de los poetas de dicha promoción. Los textos son los siguientes: dos poemas de Martín Rodríguez-Gaona ("En buenas manos", en Efectos personales, y "La eternidad está enamorada de los frutos del tiempo," en Pista de baile); el poema II de la sección "21 pepas de amor..., en 21 pepas de amor y una canción desentonada de Verónica Álvarez; "Pequeño", en Zenobia y el anciano de Ericka Ghersi, y un poema sin título de Paolo de Lima, aparecido en el primer número de la revista Carajo. Salvo el caso de "La eternidad...," todos datan de los años iniciales de la década (1990-1993). 
mente expresados en el libro, envuelven la referencia explícita a la violencia política ("días de paro armado"), que queda asociada además, aquí, a la crisis económica, a la sensación de mundo al revés y a la repetitiva percepción de un tiempo en que la muerte "es un adorno más para la vida".

Otro caso interesante de referencia expresa está en el poema "La eternidad está enamorada de los frutos del tiempo" en Pista de baile (1997) de Martín Rodríguez-Gaona. Un texto en que, previo a un letánico coro en el marco de un ficticio concierto de rock en que el vocalista llama al olvido, el hablante anuncia: "Los jóvenes bailan, / bailan sobre los cuerpos / Expurgan sus cuerpos sobre / Bosnia / Ruanda / Soccos / Tarata" (p. 53). Soccos y Tarata son nombres de lugares donde se produjeron eventos de la guerra peruana. En Soccos, Ayacucho (departamento donde surgió Sendero y el más afectado por la guerra): la ejecución extrajudicial de 32 campesinos por parte de agentes del Estado. $Y$ en la calle Tarata, en el distrito limeño de Miraflores: veinte muertos y más de cien heridos por la explosión de un coche-bomba de Sendero Luminoso.

Queda claro en el texto que la exhortación a olvidar y a bailar sobre los muertos persigue el efecto inverso: recordar estos casos como "memorias ejemplares", como diría Todorov (2000), sobre todo para contrastarlos con la dinámica central configurada en el poemario: la búsqueda desesperada, por parte de hombres y mujeres de las clases medias y altas limeñas - "jóvenes / en su mayoría, bellos en su mayoría, ajenos / en su totalidad" (p. 14)-, de emociones intensas que logren dar sentido a sus vidas y los hagan imaginarse "por una sola vez / inmortal[es]" (p. 16) en el contexto de la desbocada exaltación de todo tipo de consumo en el marco del ya consolidado escenario postutópico en el Perú neoliberal de Fujimori. Lo que quiero resaltar es que la escueta mención de dichas palabras (Soccos y Tarata), que remiten a la violencia política, en el marco del efervescente, polifónico y fragmentario retablo posmoderno de imágenes que reflejan la fuerza del individualista "imperativo goza" como mandato predominante de estos tiempos -la exhortación a la "gratificación instantánea y [...] búsqueda del placer", funcional al modelo neoliberal, que Slavoj Žižek menciona como una tendencia central en la sociedad posmoderna (2001, p. 393) - da apropiada cuenta de lo que sucedía en algunos sectores del Perú, e incluso en el propio campo poético de los noventa: la posibilidad de sentirse vivos, en un contexto de violencia y dictadura, pasaba, muchas veces, por olvidar, o por hacer cínicamente como si se olvidara lo que estaba sucediendo alrededor, aunque las marcas de esa violencia ardieran, no tan lejos, al rojo vivo.

Pero en Pista de baile hay otro espacio que también disipa la amenaza del entorno: los rituales de la vida de pareja: simples, pero capaces de brindar sensaciones de plenitud. Esta posibilidad no es una excepción: la poesía de los noventa configuró de modo recu-rrente espacios como estos: lugares privados, zonas de intimidad, recintos familiares alejados del tráfago del caos social. Es cierto que algunas veces no reflejan armonía sino conflictos internos, o hasta quiebres emocionales, pero, en general, permiten que los sujetos se mantengan a distancia de lo que ocurre afuera, aunque sus crisis puedan estar en relación con ello. Esto último se podría reconocer a partir del epígrafe del poema "Encierro", del poemario Cisnes estrangulados (1996), de Victoria Guerrero, un libro enunciado en la voz de un adolescente solipsista, amenazado por la tentación del suicidio. En el epígrafe, tomado de Van Gogh, se lee: "No sabremos nunca qué es lo que nos encierra, lo que nos cerca, lo que parece enterrarnos, pero sentimos, sin embargo, no sé qué rejas, qué paredes".

Desde esta perspectiva, propongo que el tópico del ámbito privado como espacio de refugio puede ampliarse hacia terrenos más simbólicos, como los del lenguaje. Me refiero a que determinadas concepciones de poesía y registros poéticos se establecen, a veces quizá de modo inconsciente, como mecanismos que permiten alejarse de la conflictividad social, y son, a la vez, sintomáticos de la atomización del individuo, que queda así "vaciado de la realidad" (Ángeles, 2000), o carente de lazos sociales que trasciendan lo privado. Se pueden mencionar, al respecto, la apuesta por un lirismo extremo, casi "puro", que desrealiza lo concreto, configurando, más bien, ambientes abstractos 0 etéreos, 0 la ritualización de la palabra poética en pos de lo absoluto. Incluso podrían considerarse los juegos intertextuales autónomamente literarios. En todos estos casos prevalece un lenguaje aséptico y preocupado por la corrección expresiva, y en la mayoría se evita el acercamiento a lo político 0 a las convulsiones de la sociedad. Cabe indicar que la clave de lectura que propongo para estos textos no resulta de la revisión aislada de cualquiera de ellos, sino de la recurrencia de estos rasgos en el panorama general de la promoción, en contraste con los silencios sobre la violencia política y con el contexto en que fueron producidos los poemas.

Dichos silencios pueden observarse también, paradójicamente, en muchos poemas que, desde la retórica del malditismo urbano (Chueca, 2001, pp. 80-84) heredada de la promoción anterior, sobre todo de la línea representada por el Movimiento Kloaka, exploran escenografías de descomposición, marginalidad y violencia social. Llama la atención que, en estos casos, en que el lenguaje suele ser directo e irreverente, con referencias explícitas a la miseria, la descomposición, la locura o los excesos, no haya signos equiparables que remitan a la guerra interna 0 a la dictadura, componentes centrales, más allá del texto, de esos mismos escenarios.

El caso más emblemático es el de Carlos Oliva ${ }^{4}$ (1960-1994), poetaprofeta del apocalipsis urbano cuyas "imágenes sin límites de velocidad", organizadas desde una "percepción de ángel alucinado y febril" dan cuenta 
de su decisión poético-vital de sumergirse en una ruta de descomposición de la que es testigo y partícipe. En los poemas de Lima o el largo camino de la desesperación (1995), su único y póstumo poemario, no existen alusiones a la violencia política, como si las manifestaciones de su fracturada subjetividad, y las evidencias materiales de la degradación social que configuran su correlato objetivo, no tuvieran relación reconocible con ella, sino que fueran resultado de causas invisibles e inasibles: un puro espectáculo de descomposición. Esto corresponde a inicios de los noventa, cuando la realidad exterior de los poemas era cada vez más polarizada y no ofrecía muchas más opciones a los jóvenes urbanos que elegir entre "la violencia utópica senderista" o sumarse disciplinadamente al cauce impuesto por "la dictadura neoliberal fujimorista", como ha señalado Paolo de Lima (2006, p. 51$)^{5}$.

En ese contexto, Oliva y los miembros de Neón, el grupo del que fue fundador, habrían afirmado su autorreconocimiento como un "nosotros" que revela cierta "fusión tribal" posible de ser vista como "familia" u "hogar" (De Lima, 2006, p. 57), lo mismo que su "atrincheramiento" - paralelo en algún sentido al estallido de expresiones masivas de anomia a través de las pandillas y otras "tribus urbanas"6 - en los predios de la marginalidad contracultural — poética en este caso-, que caracterizaba en parte a su actividad grupal. Aunque no se puede generalizar esta actitud a todos los miembros del grupo, es claro que a Oliva, al descartar cualquier proximidad a la violencia armada, así como una incorporación más o menos disciplinada a los diseños del neoliberalismo peruano, escogió como opción - casi como única actitud consecuente con su manera de ver el mundo - la marginalidad no solo contracultural, sino social, con todas sus implicancias. Esa es precisamente la opción que se expresa en sus poemas y la que seguramente lo condujo a la muerte.

Otro caso representativo en el marco de la aproximación a la marginalidad urbana y a la violencia social, aunque lejano de la retórica del malditismo, se encuentra en un poema de Roxana Crisólogo de Abajo sobre el cielo (1999) que se inicia con los versos "Ayer / la noche de la explosión", que podrían suponerse una alusión a un atentado senderista. No obstante, luego de esta referencia directa, el texto pasa a desenvolverse de modo velado, en concordancia con el verso siguiente, que explica: "cerré mis cortinas definitivamente". El poema, en efecto, se vuelve confuso y hasta hermético, y aunque, por momentos, parece recuperar lo explícito del inicio en un sentido que podría reforzar la hipótesis señalada, esta posibilidad vuelve a verse obstruida. No deja de ser sugerente asociar el oscurecimiento referencial que se opera en el poema con la voluntad de no ver, implicada en el cierre definitivo de las cortinas por parte de la hablante textual y, por otro lado, con el hecho de que se trata de uno de los poemas del libro cuyo sentido global se hace más difícil de asir y el único en que es posible vislumbrar alguna alusión a la violencia política.

Sin pretender establecer en profundidad las razones por las que pudieron haberse gestado los silencios, borramientos 0 veladuras en estos poetas, se pueden mencionar el miedo, el desconcierto, el desencanto, la voluntad de diferenciación, la inseguridad sobre las posibilidades de su lenguaje para abordar con la hondura necesaria dichos acontecimientos, la indiferencia ante estos hechos 0 el agotamiento del paradigma de la responsabilidad de la poesía frente a la sociedad ${ }^{7}$. Sin duda se trata de una compleja conjunción de factores que debe entenderse, además, en el contexto sociopolítico peruano de esos años ${ }^{8}$. En ese marco, los poetas que habían pensado constituir una nueva y fuerte promoción poética, solo pudieron construir un escenario de diversidad de propuestas estéticas que debe verse, si bien como un interesante aporte para el diálogo y

5 Se entiende que la opción neoliberal no implica necesariamente un optimismo frente a ella, sino más bien la aceptación, incluso la resignada en muchos casos, de participar en sus cauces del modelo establecido.

6 Sobre estas señala Martin Hopenhayn (1998) que De Lima utiliza como referencia fundamental en su ensayo: "En este contexto de exclusión, se busca crear identidades grupales, fusionarse en intersticios y márgenes, revertir la naturaleza del sistema por los bordes, los huecos, las transgresiones cómplices y casi tribales" (p. 30). Y añade que estas parecen responder "todavía a una sed de utopías: voluntad micro-política que busca aglutinarse en tribus o pequeños grupos y que quiere constituir imaginarios irreductibles a la lógica del mercado, al consenso de superestructura y a la racionalización del trabajo" (p. 31).

7 Al respecto, es interesante el planteamiento de Gustavo Guerrero respecto de lo que ha llamado el "fin de un sistema poético". Lo explica como el "cuestionamiento de los modelos de escritura que dependían de él [...y] también de las maneras de leer, de apreciar y de evaluar; [...] una puesta en tela de juicio de las perspectivas, los instrumentos y los valores con los cuales se construyó durante doscientos años un concepto del arte poética y de su campo de estudio" (p. 22). Para Guerrero, en este proceso es fundamental la puesta en crisis del sistema de valores que sostenía, desde el romanticismo alemán, la capacidad especial de la poesía y los poetas para afrontar el mundo con el "superior alcance cognitivo de la poesía" (ib íd.). En las reconfiguraciones de este sistema que se derrumba a finales del siglo XX, añade Guerrero, se puede considerar la confianza del paradigma conversacional en que la poesía podía aportar a la transformación de la sociedad y en última instancia a la revolución.

8 Un contexto marcado por la exacerbación de violencia en Lima —donde escribe la mayoría de poetas- a inicios de la década, con cotidianos coches bomba y la sospecha de que Sendero estaba alcanzando el equilibrio estratégico que le permitiría, finalmente, la toma del poder.Y luego, el inicio del gobierno de Fujimori, la traición a sus promesas de no aplicar medidas drásticas de ajuste económico, empobrecimiento y despidos masivos. Y después: el autogolpe, la dictadura y la captura de la cúpula senderista, que permitió la disminución de la intensidad de la violencia y desató optimismos que, a la vez, limitaron cualquier posibilidad de reacción frente a la consolidación neoliberal en marcha, con la ayuda, por supuesto, de represión y asesinatos selectivos, nuevas leyes laborales, destrucción de sindicatos, intervención de universidades, control de medios de comunicación, televisión basura y un largo etcétera que fue minando el ánimo crítico o rebelde de la 
la apertura, también como expresión de un "sálvese quien pueda poético": la poesía como resistencia, pero resistencia privada, temerosa, anómica, desarticulada y desconcertada frente a los embates del momento. Quizá lo único que se podía hacer.

\section{La recuperación de la voz y la memoria}

En la pregunta formulada al inicio había un segundo aspecto implicado. Pregunté por qué durante varios años la poesía de los noventa no abordó la violencia política que fue parte del contexto de su formación y su participación inicial en el campo literario. Esta formulación sugiere que hubo cambios luego de esos varios años. Efectivamente, a partir del año 2000 los silencios se fueron revirtiendo y varios poetas de los noventa han entregado libros que recorren esta preocupación no solo con interés, sino con logros estéticos importantes. Aunque también resulta imposible que me detenga ahora en un análisis de las razones de esta "recuperación de la voz", una hipótesis general es que esta se inscribe, por un lado, en las "batallas por la memoria" o por la revi- sión de lo vivido que se venía gestando desde algún tiempo atrás ${ }^{9}$, pero que gana presencia pública al caer el régimen fujimorista en el año 2000. El hito más importante de esta, aunque no el único, es el trabajo de la Comisión de la Verdad y Reconciliación, creada en 2001, con el objetivo de contribuir a esclarecer hechos y significados de la guerra interna vivida. Esto ocurrió, además, en un contexto internacional proclive a la memoria (véase Huyssen 2002; Jelin, 2012).

Pero, por otro lado, la "recuperación de la voz" de los poetas de los noventa puede verse como el paso inmediato siguiente a su interés por su reconocimiento (y autorreconocimiento) dentro del campo literario, pero ya no como "recién llegados" que pugnan, reverente 0 irreverentemente, por hacerse un sitio (como ocurrió al inicio de los noventa), sino como poetas con un capital simbólico que les permite hacer sentir su voz como palabra autorizada. Esto comienza a ocurrir ya hacia fines de los noventa y sobre todo una vez llegado el año 2000. Las posiciones que estos poetas fueron logrando les permitieron tomas de posición (Bourdieu) ${ }^{10}$ que consistieron -además de consistir en su propia creación- en trabajos críticos, reseñas, edición de revistas y participación en debates y conversatorios que brindaron particular atención a la producción generacional.
A través de estas tomas de posición, es notorio que hacia 2002 y 2003 ronda la pregunta de por qué la "poesía de los noventa" excluyó las referencias explícitas a la violencia política. En Ios años siguientes, la preocupación por estas relaciones se refleja en dos antologías confeccionadas por poetas de esta promoción: Los relojes se han roto (Bernarles y Villacorta, 2005), que califica a los noventa como "generación de la violencia", por "la atmósfera que sugiere la experiencia del terror, la crueldad, la indefensión y un espíritu de rebeldía en algunos casos autodestructivo" que se reconoce en los textos, a pesar de que "muy pocos de ellos hicieron una referencia explícita sobre acontencimientos" (p. 10). La otra es Memorias in Santas. Antología de la poesía escrita por mujeres sobre la violencia política (Crisólogo e Ildenfonso, 2007), cuyo título es suficientemente explícito.

En cuanto a la producción poética, a recuperación de la voz y de la memoria sobre la violencia política en los poetas de los noventa comienza a dar muestras de haberse iniciado ya hacia el año $2000^{11}$, pero es recién hacia 2003 que empieza a cobrar cierta visibilidad. Los años 2004 y 2005 son de mucha efervecencia al respecto y para 2007 se percibe ya consolidada esta preocupación. Para tener una idea de la magnitud de este proceso, presento a continuación una relación cronología, que Ilega hasta la actua-

juventud, en general, en el marco de procesos que William Rowe (2014) ha calificado de "vaciamiento simbólico": Rowe, a partir de Beatriz Sarlo, señala que, en el contexto de la consolidación del modelo económico neoliberal en países como el Perú, en los años noventa, se llevó a cabo un "vaciamiento simbólico" que conllevaba una violencia no declarada, a la par que contra las condiciones económicas de grandes sectores de la población, contra determinadas señas de identidad que no resultaban funcionales en los nuevos esquemas de desarrollo. En este marco se buscó establecer como inviables las ideologías izquierdistas a la vez que se pretendió crear "un vacío ético y político solo capaz de llenarse por la modernización neoliberal" (2014, p. 75), destruyéndose para ello la posibilidad de un repertorio de símbolos que pudiera ser considerado "nacional".

9 La frase "batallas por la memoria" la propongo a partir del título de un libro sobre la posguerra peruana (Hamann, 2003) y del estudio sobre la memoria de Elizabeth Jelin, quien, en su libro Los trabajos de la memoria (2012), dedica un capítulo a desarrollar la dinámica de las "luchas políticas por la memoria".

10 Bourdieu explica que las tomas de posición son "las manifestaciones de los agentes sociales comprometidos en el campo —obras literarias o artísticas, evidentemente-, pero también actos y discursos políticos, manifiestos o polémicas, etc." (1989: 4) y señala que "el espacio de las posiciones tiende a imponer el espacio de las tomas de posición: las transformaciones profundas del espacio de las tomas de posiciones, las revoluciones literarias o artísticas, sólo podrán resultar de las transformaciones de las correlaciones de fuerza constitutivas del espacio de las posiciones" (ib íd.).

11 Incluso hay muestras en el segundo lustro de los noventa que anticipan esa dirección, pero estas no aparecieron o no se evidenciaron sino hasta iniciado el nuevo milenio. Un caso es el de varios de los poemas de MDIH (2004) de Ildefonso, que remiten a la violencia política, que fueron escritos en 1995 (según ha indicado el autor) a raíz de la muerte de Carlos Oliva (Ildefonso fue integrante también de Neón). Asimismo, se puede mencionar el poema "El infierno musical" de Violeta Barrientos, que está incluido en El jard ín de la delicias, poemario de 1999. No obstante, la relación con la violencia política se hace claramente reconocible recién en la segunda edición (2006), en que al título se añade "(Perú, 1980-2000)". 
lidad, de poemas o poemarios de esta promoción que han abordado claramente la violencia política ${ }^{12}$ : Carolina 0. Fernández: Una (vela) encendida en el desierto, 2000; Alfredo Villar (el poemario apareció como anónimo): Ciudadcielo, 2001; Miguel Ildefonso: Las ciudades fantasmas, 2002; Violeta Barrientos: Trágic / Cómic, 2003; Willy Gómez: Nada como los campos, 2003; Victoria Guerrero: El mar, ese oscuro porvenir, 2003; M. Ildefonso: MDIH, 2004; V. Guerrero: Ya nadie incendia el mundo, 2005; Martín Rodríguez-Gaona: Parque infantil, 2005; Luis Fernando Chueca: Contemplación de los cuerpos, 2005; Roxana Crisólogo: Ludy D, 2006; V. Barrientos: El jardín de las delicias, 2006; Carlos Villacorta: Ciudad Satélite, 2007; Christian Zegarra: Escena primordial y otros poemas, 2007; Carolina 0. Fernández: Un gato negro me hace un guiño, 2007; Ericka Ghersi: "Mil Novecientos Noventa y Dos: Universidad San Marcos", 2007; Milagros Salcedo: "Murmullos: 69.000", 2007; Ildefonso: Los desmoronamientos sinfónicos, 2008; Víctor Coral: Parabellum, 2008; Luisa Fernanda Lindo: Postpop, 2009; Ildefonso: Dantes, 2010; V. Guerrero: Berlín 2011; Leoncio Luque: Exilio interior y otros poemas, 2011; Florentino Díaz: 28, 2013; Willy Gómez: Construcción civil y Nuevas batallas, ambos del 2013.

Varios de estos poetas, incluidos los antólogos, así como algunos otros que han trabajado críticamente sobre el tema, aunque no hayan publicado poemarios con esas coordenadas, han coincidido en diversas oportunidades en mesas de debate, coloquios 0 proyectos de revistas. Es posible, entonces, hablar de la gestación de lo que Raymond Williams denomina una estructura del sentir, que se hace perceptible hacia mediados de la década del 2000 y que evidencia la preocupación — simultáneamente poética y crítica, así como estética y política- por reflexionar sobre el pro- ceso de violencia del pasado reciente del Perú, y por indagar, desde allí, por su condición de sujetos inmersos en ese proceso.

No es posible desarrollar aquí toda la compleja diversidad de propuestas, acentos, temáticas y tensiones, expresada en la poesía de los noventa, que aborda la violencia política. Me detendré, más bien, en las páginas que siguen, en el poemario Ya nadie incendia el mundo (2005) de Victoria Guerrero, que puede reconocerse como un caso emblemático de este proceso. En él se puede reconocer una serie de preocupaciones que atraviesan la producción sobre la violencia política de la promoción en el nuevo contexto: la pérdida de la voz como marca "generacional", la importancia de la mirada "de género", el cuerpo y la familia como metáforas de la nación, los dispositivos del biopoder autoritario, la pérdida de la utopía y la preocupación por recuperarla, el autoexilio, la articulación vida-poesía, la dimensión crítica y política de la poesía, la indisociabilidad entre lo íntimo y lo público, así como la pregunta sobre las posibilidades del lenguaje de enfrentarse a todo ello, entre otros. Ya nadie incendia el mundo es, además, sin duda, uno de los textos más interesantes de los noventa que se inscriben en esta revisión del pasado reciente y, en general, uno de los poemarios más sólidos entre los publicados en las últimas décadas en el país.

\section{Ya nadie incendia el mundo de Victoria Guerrero: nación, esterilidad y utopía ${ }^{13}$}

\section{Historia personal, historia nacional y escritura}

En una de sus lecturas posibles, Ya nadie incendia el mundo puede verse como un poemario que aborda centralmente la historia de la mujer protagonista $-\mathrm{y}$ sujeto hablante del libro - que recorre episodios de su propia vida: desde su nacimiento, luego de siete meses de ser gestada, pasando por la constatación de su esterilidad (porque "otra vez no hay menstruación / sino solo pestilencia") y sus reiteradas visitas a médicos y hospitales (a causa de esto y del cáncer al seno de su madre), hasta llegar, finalmente, a la conciencia de su desarraigo en un lugar ajeno. No obstante, limitarse a esa perspectiva resultaría empobrecedor, pues dicho recorrido - bullente y fragmentadose construye a través de, al menos, tres niveles que se desarrollan en paralelo: un discurso que se propone como autobiográfico (que invita a que el lector identifique a la protagonista con la autora), una reflexión metapoética y un diálogo entre las circunstancias de la vida de la poeta-hablante textual y las atravesadas por el Perú en las décadas recientes de guerra interna y dictadura civil. La inseparabilidad entre dichos planos resulta clave en la estructura del conjunto, pues cada uno de ellos ilumina a los restantes.

El primer nivel (autobiográfico), que va siendo reconocible, por ejemplo, a partir de la decisión de la autora de utilizar su año de nacimiento como punto de partida de la historia trazada, así como por la mención de su residencia fuera del Perú en los momentos de la escritura del libro, entre otros datos comprobables de su biografía, se refuerza al inscribir, en el último poema del libro, su nombre propio como firma y como huella de esperanza en la lucha ante las adversidades y el dolor

12 Como en todos los casos anteriores, se trata de un listado necesariamente incompleto, pero representativo y que atienden, en general, a la producción más relevante o más difundida.

13 Una versión preliminar de esta sección fue publicada en "Nación, esterilidad y utopía en Ya nadie incendia el mundo de Victoria Guerrero", en De Vivanco Roca Rey, Lucero (ed.). Memorias en tinta. Ensayos sobre la representación de la violencia política en Argentina, Chile y Perú. Santiago: Universidad Alberto Hurtado, 2013, pp. 419-434. 
mostrados en todo el recorrido: "con esperanza / victoria" son las palabras con que cierra el poemario. El segundo nivel (metapoético) se constata en el poema de apertura, "Lima / año cero", que ofrece, entrelazada con los primeros trazos con que la hablante se autopresenta, una reflexión que se mantendrá en lo sucesivo sobre la simultánea im/posibilidad y necesidad de la escritura:

voy porfiando tercamente garabateando una escritura que no sana el cuerpo explota revienta en miles de pedacitos de odio ¿los quieres? recoge uno tras otro con cuidado para que no te hieran y luego a la basura sin lágrimas. (p. 13)

La escritura de este poema, en prosa abigarrada y sin signos de puntuación, se equipara a lo que anuncia: fragmentos, pedazos, restos (en lenguaje quebradizo y, por ello, punzante) de un recorrido plural. El tercer nivel (diálogo con las circunstancias vividas en el Perú) aparece incrustado, como se observa en la cita anterior, entre los otros: "el cuerpo explota revienta en miles de pedacitos" (cursivas mías), por ejemplo, alude también, entre otras posibilidades, a la guerra interna y la dictadura. Este nivel se traza, además, y de la misma forma, como desarrollaré más adelante, a partir de fechas consignadas en los títulos de varios de los poemas. De este modo, ocurre con Ya nadie incendia el mundo Io que Deleuze y Guattari afirman sobre las literaturas menores: "cada problema individual se conect[a] de inmediato con la política [...] todo adquiere un valor colectivo" (1990, pp. 29-30), con lo que el poemario, como se verá, establece su "posibilidad de expresar otra comunidad potencial, de forjar los medios de otra conciencia y otra sensibilidad" (p. 30).

Descontando los poemas de apertura y cierre del conjunto, el poemario está estructurado en dos secciones: "pabellón nacional / NACIMIENTO Y CAÍDA" y "pabellón 7A / SACRIFICIO". El paralelo entre ambos títulos, a partir de la polisemia de "pabellón", revela la conjunción aludida: la bandera patria y un sector del Hospital del Empleado de Lima. El símbolo nacional se vincula de este modo con el inicio de la vida de la protagonista, así como luego un internamiento en dicho "pabellón" del hospital le permitirá atestiguar el sacrificio (ritual, pero quizá inútil en sí mismo), inmerso en la trama de descomposiciones y agonías sociales del país, de un compañero de promoción poética. La primera sección se abre con "Hospital del Empleado / 1971", poema que presenta las circunstancias del nacimiento de la protagonista, quien, por tratarse de una sietemesina que requiere de una incubadora ("vientre frío" o "máquina-madre"), se percibe a sí misma incompleta -en su retrospección, aunque articulada sobre todo en tiempo presente- $-y$ es objeto de un trato marginador y excluyente, lo que le hace posible calificar ese momento como una situación de "caída" simultánea al "nacimiento" (los dos sustantivos resaltados en mayúsculas en el título de la sección):

\section{niña idiota}

-dijeron

aspira más allá de tu cuerpo defectuoso y lárgate

ya no tenemos espacio para ti ni los tuyos (p. 20).

El desprecio de los representantes del saber institucional hacia ese cuerpo abyecto que pugna por vivir, evidenciado en el uso reiterado de imperativos en el poema ("lárgate", "escóndete", "vete"), que buscan lograr su ausencia y desaparición, provoca que la niña-hablante intente la afirmación de su frágil identidad frente a la amenaza omnipresente del orden autoritario que establece, a través de la alianza entre discurso médico y moral, las construcciones normativas de la sociedad (Anz, 2006, p. 32). En ese marco en que la niña comienza a percibir la tajante e injusta división entre lo bueno y lo malo o lo útil y lo inútil según la normatividad establecida, reconoce por primera vez una imagen que será leitmotiv en toda la sección: "un mar te alcanza / un mar podrido repleto de cadáveres / te moja los pies" (p. 22), ${ }^{14}$ con la que simultáneamente se confirma la condición de sobreviviente de la protagonista (pasible de convertirse en uno más de los cadáveres de ese útero enorme que es el mar), se alude a su esterilidad (en la medida en que la pestilencia regada a sus pies podría evocar la menstruación que, paradójicamente, evidencia en su caso la incapacidad de engendrar vida) y se sugiere el alcance nacional de la imagen, pues estos cadáveres remiten también, inevitablemente, a los muertos de la guerra interna peruana.

En contrapunto con ello, en el mismo poema, la protagonista vislumbra los primeros signos de que algo distinto es posible, aun sea algo frágil como la imaginaria luz del viejo Parque de la Media Luna en el distrito limeño de San Miguel —otro guiño autobiográfico-, que se ofrece como símbolo inicial de la apuesta utópica ("subo hasta lo alto de tu media luna / me paro de puntillas / intento / el equi- / librio / san miguel flota entre la neblina / todo es blanco blanco / blanco y armonioso / ¿es esta nuestra pureza?"; p. 23) que la hablante tercamente sostendrá en todo el libro a través de su escritura enfrentada a la amenaza del silencio y a los límites de la representación.

Lo señalado da una idea inicial de las estrategias que articulan los niveles en Ya nadie incendia el mundo. Como hemos visto, las situaciones referidas, si bien ancladas en el plano biográfico, son también claros indicios de la sociedad: una sociedad excluyente, autoritaria, violenta y abusiva que integra biopolíticas y tanatopolíticas entre sus procedimientos disciplinarios y de control (Foucault, Agamben). La escri-

14 El anterior poemario de Victoria Guerrero, con el que este libro tiene muchos puntos en contacto (temáticos, textuales y simbólicos) se titula, precisamente, El mar, ese oscuro porvenir (2003). 
tura que nos muestra lo anterior - que relaciona, en el poema mencionado, voces que se interpelan mutuamente, pero que no hacen posible un diálogo - será objeto de una permanente puesta en cuestión de su valor y su posibilidad, haciendo de ese mismo cuestionamiento la condición de su existencia.

El poema "1980-1984 a secas" retoma, desde el "a secas" del título, el asunto de la agónica lucha de la protagonista —aquí representada como niña y adolescente- por un lenguaje (y luego una escritura) que desafíe -porque solo así logrará acercarse a decir lo que desea- las convenciones de corrección, pureza e higiene que tratan de imponérsele. Evidencia, además, la inseparabilidad entre cuerpo y palabra, a la vez que ambos campos se proponen como espacios de resistencia y oposición frente a la corriente normalizadora de la sociedad y permiten, en ese sentido, afirmar la voluntad transgresora de lo que será su propuesta po/ética: "mírate en un espejo no eres tú la que habla la que habla se esconde bajo tus calzones y balbucea estira la mano y se escabulle frente a una máquina de escribir flexible siempre dispuesta a la corrección despréciala borra su estúpida poesía la necia higiene de sus palabras todas ellas solo conducen a un gran desbarrancadero" (p. 30). Al final de este texto se pone en escena un recorrido familiar en automóvil que simboliza a la vez una sumersión en espacios oscuros y amenazadores de la urbe ("húndete bajo tus zapatos acepta el desprecio de ser ajeno bajo el gris de una ciudadcielo"; p. 31) en los que, como advertencia, aparece un característico cartel que se leía en los muros de los recintos militares durante los años de violencia política:

PRO-HI-BI-DO-DE-TE-NER-SE HAY-OR-DEN-DE-DIS-PA-RAR

De esa tensa exploración "en el mar en la sucia espuma que baña los abismos", parece nacer la escritura de este libro (fragmentaria, balbuceante a ratos, violenta en su sintaxis y su vocabulario), que desemboca, en el poema "7 años de silencio/1985-1991", en un macabro juego de variaciones. En él leemos (casi) todas las posibilidades combinatorias de la frase "las imágenes de los cadáveres descompuestos pasan gélidas ante nuestras narices como carne muerta desde el nacimiento" —oración que ya había aparecido

\section{7 años de silencio}

(1985-1991)

las imágenes de los cadáveres descompuestos pasan gélidas ante nuestras narices como carne muerta

—desde el nacimiento

las imágenes de los cadáveres des/compuestos

pasan flotando gélidas ante nuestras narices ¿como carne muerta desde el nacimiento?

las imágenes

de los cadáveres descompuestos pasan

FLOTANDO

ante nuestras narices g-é-l-i-d-a-s como carne muerta desde el nacimiento

las imágenes gélidas

de los cadáveres descompuestos

pasan flotando ante nuestras narices

COMO carne muerta desde el nacimiento (pp. 33-34).

atravesando el margen inferior de la página, como un cintillo cinematográfico con cuya reiteración se pretende grabar una información, en el poema previo y aparecerá en el posteriorque se convierten, así, en la única y obsesiva realidad perceptible:

El silencio propuesto por el título obviamente se relaciona con las dificultades de lograr la palabra y la escritura necesarias para hablar de aquello, sociedad, "hundimos nuestros dedos en las cuencas vacías / de nuestros deseos" (p. 35). El 'doble vaciado' al que me refiero es una página en blanco en la que solo está escrito el título, "7 años + de silencio / 1993-2000", y en la parte baja la escueta frase " $y$ nadie Ilorô" (p. 41; cursivas originales).

Las fechas son reveladoras. El corte entre ambas secuencias ("1985-1991" y "1993-2000") corresponde al

15 Esto se desprende de las posibles relaciones entre el silencio planteado y la afirmación de que "pertenezco a una generación muerta" que se leerá en un poema posterior. Sobre esto regresaré más adelante. 
poema, colocado como bisagra, "Días de 1992", de donde tomé la cita "hundimos nuestros dedos en las cuencas vacías de nuestros deseos". Ese año, recordemos, fue el de mayor número de atentados en Lima en todo el periodo de la guerra interna, el del inicio de la dictadura y el de la captura de Abimael Guzmán: un año emblemático en la historia reciente del país. Los siete años de silencio previos, de 1985 a 1991, pueden atribuirse, como señalé, a la sociedad en general, pero quizá sobre todo a los poetas que vivieron ese tiempo en silencio (poético), abrumados por la incertidumbre frente al espectáculo de la muerte rodeándolo todo, y por la incapacidad de procesarlo debida a cierta indiferencia (casi forzada, como la ceguera) y al desencanto que empezaba a aparecer, como se desprende de la imagen de las "cuencas vacías de nuestros deseos". Son los momentos en que estos poetas, adolescentes todavía, que comenzaban a escribir 0 a relacionarse más abiertamente con el mundo de lo público -que supuestamente debía generar en ellos utopías colectivas y entusiasmos juveniles de rebeldía y emancipación, como había ocurrido con sus antecesores-, solo veían las paralizantes "imágenes de los cadáveres des/compuestos", que conducen a que ellos sean percibidos, de algún modo, también, como cadáveres: "nosotros / los que hoy caemos más allá / en lo más bajo de nosotros mismos / a cuyos pies postrada y pálida se muestra / nuestra negra adolescencia" (p. 35).

En 1992, como he señalado, se abrió otra etapa: el inicio de la dictadura y la disminución de la intensidad de la vioIencia, que se hace más evidente a partir de 1993. Si bien la menor violencia pudo haber sido la oportunidad para que estos poetas, terminada su etapa adolescente, miraran lo que había ocurrido y lo que estaba ocurriendo con más detenimiento y capacidad reflexiva, ellos, más bien, como buena parte de la sociedad peruana y de los poetas, se sumergieron, en el marco de la normalización de la dictadura, en un silencio aún mayor, que provocó su sensación de duelo irresuelto: "y nadie Iloró", como dice el único verso de "7 años + silencio / 1993-2000". Lo que prevaleció en ellos, en efecto, en ese contexto de miedo y disciplinamiento, fue, como se verá también a partir de las metáforas del cuerpo y la enfermedad que abordaré en el siguiente acápite, la parálisis y la renuncia, así como la incapacidad de evaluar, en esos momentos, su propia actuación en ese proceso.

De todo ello, que se refuerza incluso visualmente con el vacío casi total de la página, parece tomar aguda conciencia la hablante en el presente de enunciación, que en "Días de 1992" se reitera como el "ahora" desde el que se realiza la retrospección. Ese presente, además, está localizado en un "aquí" físicamente distante del país ("allá"). Es desde estos nuevos momento y lugar que se pugna por la recuperación de la memoria y la voz. El libro es, de algún modo, la puesta en escena del proceso.

\section{Enfermedad, cuerpo y nación}

En la segunda sección, "pabellón 7A / SACRIFICIO", el tema de la enfermedad pasa a primer plano. La esterilidad de la protagonista y el cáncer de su madre provocan que varios de los poemas se desarrollen en salas de hospital y que la sección se impregne de un léxico fisiológico, quirúrgico y escatológico que coloca al cuerpo como protagónico de luchas, castigos y resistencias que, a su vez, lo trascienden. Los dos primeros poemas ofrecen sendas escenas médicas vinculadas con la hablante textual: el primero ("Habitación 20012002-2003”), una disección (llamada "ritual de aniquilamiento") destinada a retirar "las partes putrefactas" de su cuerpo, y el otro ("Continua escasez de agua en todo el territorio nacional 1980-2004") presenta una secuencia de intervenciones que posiblemente intentan revertir su infertilidad. En ambos casos, la hablante vincula estas escenas con situaciones ocurridas en el exterior del hospital: en el primero menciona que la disección no le impide "entrever por las rendijas / [...] / los cuerpos hundidos en el acantilado" y, en el segundo, habla de fusilamientos $y$ alude a "la falta de agua [y] la continua explosión callejera” (p. 51), con lo que nuevamente se establecen las correspondencias entre la trama íntima y el espacio nacional: los castigos y mutilaciones ocurren simultáneamente en el cuerpo y en el exterior del hospital. En ambos, igualmente, Ios médicos son agentes de foucaultianas estructuras de vigilancia que combinan las prácticas biopolíticas de la sociedad disciplinaria con las de una sociedad de control ${ }^{16}$. En "Habitación 2001-2002-2003", por ejemplo, a la primera disección ("la sangre inocente chorrea / es un alegre surtidor que baña nuestros rostros", 49), le sigue su réplica:

\section{"ES AQUÍ CUANDO EMPIEZA LA SEGUNDA DISECCIÓN}

la estación del sacrificio y la re-educación:

vaciar el cuerpo de todo animal ajeno cargando el olvido entre los brazos PARA QUE NINGÚN MAL NOS SALPIQUE (p. 51; mayúsculas originales).

La mencionada extracción, de este cuerpo femenino, de todo lo considerado "animal" y el correspondiente intento reeducador que busca eliminar lo que transgreda la normatividad social e instaurar una engañosa comodidad basada en el olvido son acciones equivalentes a las de los "polis" (policías) que en varios poemas aparecen "pateando nuestros sueños". Así, médicos y policías tienen en común la necesidad, para sus respectivas tareas,

16 Mientras que la sociedad disciplinaria opera "mediante la organización de grandes centros de encierro" (Deleuze, [1990]1999), en la sociedad de control "los mecanismos de dominio se vuelven aún más 'democráticos', aún más inmanentes al campo social, y se distribuyen completamente por los cerebros y los cuerpos de los ciudadanos, de modo tal que los sujetos mismos interiorizan cada vez más las conductas de integración y exclusión social adecuadas para este dominio" (Hardt y Negri, 2002, p. 36). 
de fijar claramente las fronteras entre lo sano y lo enfermo, lo humano y lo animal, lo permitido y lo prohibido, lo benigno y lo dañino, de manera tal que puedan alejar (extirpar) lo "ajeno" a lo determinado por el orden oficial. La hablante textual, sin embargo, resiste la invitación al olvido, puesto que considera que la memoria áspera y agitada y su correspondiente escritura son algunas entre las pocas vías que permiten los replanteamientos profundos. En el siguiente poema, "Continua escasez de agua en todo el territorio nacional/1980-2004", los médicos, que proceden a una suerte de seriada violación simbólica de la hablante textual para lograr normalizarla y acabar de ese modo con su esterilidad, son mencionados por esta como "carniceros" e incluidos en la serie "carniceros doctores héroes nuestros" (p. 55), con lo que es posible una identificación entre su rol social y su catadura moral y humana, y la de los llamados "héroes de la patria"17.

El poema que le da el título a la sección ("Pabellón 7A / SACRIFICIO") vuelve sobre esta omnipresencia médica. Se inicia con un contrapunto entre la imagen de la mano que realizará la operación — vista, gracias a un mecanismo de repetición sintagmática, cada vez más en primer plano-, y la autorreferencia de la propia hablante, objeto de dicha intervención, cuya reacción ("yo me duermo babeo voto mi espuma" (p. 61) resalta el componente de violencia en el trato que se le inflige. Los médicos enarbolan ahora directamente las consignas de "NO GRITES NO VIVAS NO AMES" (p. 61) 0 "QUÉDATE Y SERÁS FELIZ" (p. 62; mayúsculas originales). Nuevamente la pasividad y el olvido como pro- puestas oficiales de diseño de la vida social. Nuevamente la cárcel de un conformismo (la habitación de hospital se equipara a una prisión) cuya quietud es oportunamente contrastada por el poema con el sonido de un balazo a medianoche 0 con la imagen de un mutilado que avanza por una avenida sintomáticamente llamada "Perú".

La hablante del poema contrapone también la engañosa luz de una lámpara, en medio de oníricas sensaciones - seguramente consecuencia de fármacos utilizados en la nueva operación normalizadora - , con la luz que despliega el fuego encendido por un poeta -que podemos identificar con el poeta Josemári Recalde (19732000)—, que "incendia su cuerpo en medio de la noche" y "se agita en llamas de su propia orfandad" (p. 63) y a quien la hablante textual le dirige la frase de donde emerge el título del poemario: "YA NADIE INCENDIA EL MUNDO / NI SIQUIERA TÚ" (p. 64; mayúsculas originales). El libro rechaza, así -en paralelo al desprecio de la escritura "correcta", "limpia" y lineal-, el pulcro y blanquísimo recinto ofrecido como recompensa por el adormecedor tratamiento médico, para acercarse a otros espacios que le permiten confrontarse con ( 0 afrontar) aquello doloroso y violento que se le pide olvidar. De esa confrontación resurge el deseo utópico. El mundo requiere, parece sugerirse, de un incendio, pero que no sea solo síntoma extremo de la desesperación y el desencanto, como en el caso del poeta autoinmolado ${ }^{18}$, sino de fuego capaz de mantener vivo un horizonte que (casi) todo se empeña en apagar. En "Fiesta / 2004 (Hospital del Empleado)", el cuerpo estéril y sujeto a suce- sivas disecciones de la hablante se identifica con el cuerpo enfermo y también mutilado de su madre. Se diseña, así, una cierta línea de continuidad que podría reconocerse como herencia simbólica: un mal que pasa de madre a hija. El cuerpo de la madre (su "seno cercenado", p. 65) remite, entonces, al cuerpo enfermo de una sociedad que históricamente no ha llegado a constituirse en nación, y menos en nación justa y democrática: una imposible comunidad imaginada (Anderson) que deja su herencia inevitable de violencia y sistemas de exclusión, y que provoca por ello la incapacidad para la reproducción de una vida plena y libre. A su vez, las disecciones y mutilaciones de que son objeto madre e hija pueden verse, de algún modo, como representaciones de la nación que, en el contexto específico de la violencia política, buscó el camino para la recuperación de su "tranquilidad" en la extirpación del "cáncer social"19. en una política de guerra sucia que provocó las reiteradas "imágenes de los cadáveres descompuestos [que] / pasan gélidas flotando ante nuestras narices", sin preocuparse casi por articular soluciones políticas y sociales para las causas que hicieron posible el estallido de la violencia armada.

No resulta un despropósito, entonces, el lacerante contraste entre la imagen "desnuda en una camilla de hospital / mi madre se tiende del lado opuesto del seno cercenado" (p. 65), con que se abre este poema, con la tradición de representación de la patria (y de la libertad buscada y, eventualmente, alcanzada por esta) como mujer desnuda con los senos a la vista, como se ve, por ejemplo, en el famoso cuadro La libertad guiando al pueblo (1830)

17 Aunque el poema no pone en escena un conflicto étnico, es interesante la riqueza de asociaciones posibles entre los poemas y la historia del país a partir de la relación entre la violación simbólica y el arco médico-héroe nacional-policíacarnicero. Por un lado, se puede considerar la violación (real, en estos casos) como símbolo de la relación entre los soldados españoles y las mujeres indígenas a partir del ingreso "Perú" en la historia occidental. Este tipo de violaciones se han seguido produciendo a lo largo de la historia nacional hasta llegar a las producidas en el contexto de la guerra interna por parte de los supuestos "héroes de la patria" (militares y policías). En unos y otros casos, el cuerpo femenino utilizado como "botín de guerra" (Silva Santisteban, 2007, p. 11). Por otro lado, en relación con la figura del médico como dispositivo del biopoder autoritario durante los tiempos de la violencia política, pueden evocarse las esterilizaciones forzadas del fujimorismo como formas de violación.

18 Sobre su presencia en el poema, Susana Reisz ha dicho que la frase "sugiere un cuestionamiento del alcance y el sentido (¿político?) del sacrificio individual y, al mismo tiempo, una cierta nostalgia del Apocalipsis" (2006, p. 159).

19 Señala Susan Sontag que "la utilización del cáncer en el lenguaje político promueve el fatalismo y justifica medidas 'duras'. [...] Nunca es inocente el concepto de enfermedad, pero cuando se trata de cáncer se podría sostener que en sus metáforas va implícito todo un genocidio" (1984, p. 125). 
del francés Eugène Delacroix, mencionado muchas veces como el primer cuadro político de la pintura moderna. Pero mientras en el caso de Delacroix, la mujer encabeza una lucha colectiva, mostrando sus senos como desafiante imagen de libertad y vitalidad, la patria, simbolizada en el poema por la madre, solo puede mostrar el espectáculo abyecto y solitario de su mutilación.

La afección que sufre la hija se corresponde, al mismo tiempo, con la heredada y asentada sobre la "generación" a la que cronológicamente corresponden la poeta-protagonista del libro y sus compañeros de ruta, los "poetas de los noventa": al declarar "madre / pertenezco a una GENERACIÓN MUERTA" (p. 67; mayúsculas originales), parece estar poniendo en escena el adormecimiento colectivo y el silencio poético de los poetas de los noventa. La imposibilidad de aquella promoción de escritores que, como anoté, envueltos en el desencanto, la abulia, el miedo 0 el desconcierto, alejaron de su palabra poética, a pesar de las urgencias del tiempo (los reales cadáveres de los años ochenta y noventa que pasaban y pasaban insistentemente ante sus narices, y los simbólicos reflejos de sus propios cadáveres en tanto hombres y mujeres cuyas esperanzas se presentían muertas), toda referencia directa a esto, y establecieron muchos de ellos sus refugios en los espacios de la individualidad20; así evitaban, supuestamente, el contacto con lo político: la desesperanza absoluta sobre los destinos del país se tradujo muchas veces en la celebración de rituales de intimidad o las reverencias a la perfección de la palabra. Al respecto, en un testimonio sobre esta promoción poética escrito por Guerrero escrito en 2006, señala que "[h]abía que sobrevivir como se pudiera, el silencio era una de esas formas" (Guerrero, 2007). Contra todo eso es, precisamente, contra lo que la escritura de este libro persiste en rebelarse.

\section{"Contradanza": utopía e "iniciativa de salud"}

Los últimos poemas del libro ofrecen nuevas imágenes de la terca y frágil resistencia de la poeta-protagonista. Ella insiste en realizar una "contradanza" (título de uno de los poemas) en la que afirma:

"conjuro a la muerte este día con una danza de gloria y porvenir le escupo a la enfermedad la maldigo

como maldigo a la mosca

que todas las noches canturrea sobre mi cabeza" (p. 69).

No se puede dejar de observar la carga de violencia verbal en esta "contradanza" de la hablante ("escupo", "maldigo", "grito"), como si solo así pudiera lograr —aunque sea incipiente y momentáneamente- que la muerte "agach[e] la cabeza en un rincón de la pared blanquecina" (p. 70). Se enfrenta de ese modo a su propia oscuridad y a la sensación de abatimiento que no cesa de amenazar con envolverla, a la vez que a una nueva aparición de "la policía de los sueños", que se encuentra ahora arrastrando "los últimos muertos" (p. 81).

De allí que terminar el libro con la frase "con esperanza / victoria" (p. 81) no sea solo un sello, como anoté, de la identificación entre protagonista y autora, sino también una consciente declaración de su proyecto po/ ético-político ${ }^{21}$. La dimensión utópica contenida en esta frase no pretende dar cuenta, sin embargo, de una victoria definitiva ante la enfermedad, ni ante la sociedad de vigilancia, ni ante la violencia y la muerte. Tampoco equivale a un triunfo frente al silencio que cubrió con su manto a un grupo de poetas y a gran parte de la sociedad peruana (que se hizo, así, en parte, cómplice de lo que sucedía en el periodo de violencia política y dictadura civil que atravesó el país), pues, como se lee en el fragmento citado, la mosca de la muerte sigue canturreando sobre la cabeza. Con todo, articular las ásperas y quebradas palabras de este libro, estar por fin "vomitando su silenciamiento" —como ha dicho Victoria Guerrero (2007), a propósito de lo que sucede en los últimos tiempos con ella y varios de los poetas de su promoción- es sí una victoria: la luz de un pequeño fuego imprescindible que remite a la necesidad de una lucha (vital y de escritura) sostenida.
Representa, en ese sentido, una fuerza que contrarresta la esterilidad social - desde la limitada pero reveladora y sintomática capacidad de conmoción que tienen el arte y la literatura-. Una persistencia que busca, entonces, revertir el nefasto papel de los doctores presentes en las páginas del poemario (y la propia conciencia metapoética de porfiar en "una escritura que no sana el cuerpo" con que se iniciaba el poemario), para actuar, a su vez, como "iniciativa de salud" frente al "mundo [que] es el conjunto de síntomas con los que la enfermedad se confunde con el hombre", como señala Deleuze (1996, p. 14), quien añade que "la salud como literatura, como escritura, consiste en inventar un pueblo que falta [...]. No escribimos con los recuerdos propios, salvo que pretendamos convertirlos en el origen 0 el destino colectivos de un pueblo venidero todavía sepultado bajo sus traiciones y renuncias" (Deleuze, 1996, p. 15). Es posible sostener que Ya nadie incendia el mundo se inscribe, de algún modo, en esta perspectiva: busca aportar, en el caso peruano, a la necesaria revisión y comprensión (a través de medios que implican, pero exceden también —en tanto poesía-, la razón y la reflexión) del pasado reciente, ofreciendo una memoria diferente tanto de las que se organizan desde la documentación histórica o el análisis sociológico, así como de otras surgidas desde las artes. Un necesario

20 Un caso emblemático de esto, como vimos, es Cisnes estrangulados (1996), segundo libro de Victoria Guerrero.

21 Que tiene una clara continuidad en Berlín, siguiente poemario de la autora, publicado en 2011 y en Cuadernos de quimioterapia (contra la poesía), aparecido en el 2012. 
acercamiento —en esa conjunción de esfuerzos diversos- a lo que sociedad e individuos fueron y son, que contribuya -en esa conjunción de esfuerzos diversos- no solo a enfrentar las versiones oficiales sobre lo acontecido, sino a articular una todavía naciente (y muy frágil) sensibilidad más abierta, justa y no excluyente.

\section{Bibliografía}

Agamben, G. (2000). Lo que queda de Auschwitz. El archivo y el testigo. Homo sacer III. Valencia: Pre-Textos.

Agamben, G. (2010). Homo sacer. El poder soberano y la vida nuda. Valencia: Pre-Textos.

Álvarez, M. (1991). Zona dark. Lima: Edición de la autora.

Anderson, B. (2000). Comunidades imaginadas. Reflexiones sobre el origen y la difusión del nacionalismo. Buenos Aires: Fondo de Cultura Económica.

Ángeles, C. (2000). Los años noventa y la poesía peruana. A propósito del libro Cansancio, de Paolo de Lima, y otros poemas inéditos. Ciberayllu [portal en línea]. Recuperado de http://www.andes.missouri.edu/andes/Especiales/ CALNoventa/CAL_Noventa1.html

Anz, T. (2006). Argumentos médicos e historias clínicas para la legitimación e institución de normas sociales. En W. Bongers (comp.). Literatura, cultura, enfermedad (pp. 29-45). Buenos Aires: Paidós.

Bernales, E., y Villacorta, C. (eds.). (2005). Los relojes se han roto. Antología de la poesía peruana de los noventa. México, D. F.: Arlequín.

Bourdieu, P. (1989-1990). El campo literario. Prerrequisitos críticos y principios de método. Criterios, (25-28), 20-42. Recuperado de http://www.criterios.es/pdf/bourdieucampo.pdf

Chueca, L. F. (2001). Consagración de lo diverso: una lectura de la poesía peruana de los noventa. Lienzo (22), 61-132.

Chueca, L. F. (2009). ¿La hegemonía de lo conversacional? Notas para continuar una discusión. Intermezzo Tropical, (6-7), 134-140.

ChuecA, L. F. (2013). Nación, esterilidad y utopía en Ya nadie incendia el mundo de Victoria Guerrero. En L. De Vivanco Roca Rey (ed.), Memorias en tinta. Ensayos sobre la representación de la violencia política en Argentina, Chile y Perú (pp. 419-434). Santiago: Universidad Alberto Hurtado.

CRisólogo, R. (1999). Abajo, sobre el cielo. Lima: Nido de Cuervos.

CRisólogo, R., e Ildefonso, M. (eds.). (2007). Memorias in santas. Poesía peruana escrita por mujeres sobre la violencia política. Lima: Demus y Centro de la Mujer Peruana Flora Tristán.

Deleuze, G., y Guattari, F. (1990). Kafka. Por una literatura menor. México, D. F.: Era.

Deleuze, G. (1996). Crítica y clínica. Barcelona: Anagrama.

Deleuze, G. (1999 [1990]). Post-scriptum sobre las sociedades de control. En G. Deleuze, Conversaciones, 19721990 (pp. 277-281). Valencia: Pre-Textos. Recuperado de http://www.oei.org.ar/edumedia/pdfs/T10_Docu1_ Conversaciones_Deleuze.pdf.

De Lima, P. (2006). Atrincheramientos y balbuceos neotribales: El grupo poético Neón entre la violencia utópica senderista y la dictadura neoliberal fujimorista. El caso de Carlos Oliva. A Contracorriente: Revista de Historia Social y Literatura en América Latina, 3(2), 51-72. 
Foucault, M. (2001). Un diálogo sobre el poder y otras conversaciones. Madrid: Alianza Editorial.

Guerrero, V. (1996). Cisnes estrangulados. Lima: Cuernoenpanza.

GUeRrero, V. (2002). El mar, ese oscuro porvenir. Lima, Santo Oficio.

Guerrero, V. (2005). Ya nadie incendia el mundo. Lima, Estruendomudo.

GUerRero, V. (2007). Entre el desencanto y la violencia - a manera de testimonio-. Ómnibus, II/(13). Recuperado de http://www.omni-bus.com/n13/guerrero.html.

Guerrero, V. (2011). Berlín. Lima: Intermezzo tropical.

Guerrero, V. (2013). Documentos de barbarie (Poesía, 2002-2012). Lima: Paracaídas.

Hamann, M., López Maguiña, S., Portocarrero, G., y Vich, V. (eds.). (2003). Batallas por la memoria. Antagonismos de la promesa peruana. Lima: Red para el Desarrollo de las Ciencias Sociales en el Perú.

Hardt, M. y Negri, A. (2002). Imperio. Buenos Aires: Paidós.

Huyssen, A. (2002). En busca del futuro perdido. Cultura y memoria en tiempos de globalización. México D. F.: Fondo de Cultura Económica.

Jelin, E. (2012). Los trabajos de la memoria. Lima: Instituto de Estudios Peruanos.

OLIVA, C. (1995). Lima o el largo camino de la desesperación. Lima: Hispano Latinoamericana.

ReIsz, S. (2006). De incendios y regresos imposibles: un nuevo poemario de Victoria Guerrero. Hueso Húmero, (48), 146-161.

Rodríguez-Gaona, M. (1992). Efectos personales. Lima: Ediciones de los Lunes.

Rodríguez-Gaona, M. (1996). Pista de baile. Lima: Santo Oficio.

Rowe, W. (2014). Hacia una poética radical: Ensayos de hermenéutica cultural. México, D. F.: Fondo de Cultura Económica.

SAID, E. W. (2004). El mundo, el texto, el crítico. Buenos Aires: Debate.

Silva Santisteban, R. (2007). Las hijas del terror. Lima: Copé.

SonTAG, S. (1984). La enfermedad y sus metáforas. Barcelona: Muchnik.

Todorov, T. (2000). Los abusos de la memoria. Barcelona: Paidós.

Wilıiams, R. (1997). Marxismo y literatura. Barcelona: Península.

ŽıžEK, S. (2001). El espinoso sujeto. El centro ausente de la ontología política. Buenos Aires: Paidós. 